\title{
Erythrocyte Nucleotides in Children-Increased Blood Lead and Cytidine Triphosphate
}

\author{
CAROL R. ANGLE, ${ }^{(20,26)}$ MATILDA S. MCINTIRE, MARK S. SWANSON, AND SIDNEY J. STOHS \\ Departments of Pediatrics and of Biomedicinal Chemistry of the University of Nebraska Medical Center, \\ Omaha, NE, USA
}

\begin{abstract}
Summary
The erythrocyte nucleotides of 25 children, 1-5 years old, with normal and increased blood leads, were assayed by anion-exchange high-performance liquid chromatography. Red blood cells of the 12 children with blood lead (PbB) below $30 \mu \mathrm{g} / \mathrm{dl}(20.3 \pm 6 \mu \mathrm{g} / \mathrm{dl}$, $\overline{\mathbf{X}} \pm$ S.D.) had normal levels of activity of pyrimidine $5^{\prime}$-nucleotidase (P5N) and their erythrocytes were virtually free of pyrimidine nucleotides except for small amounts of UMP and UDP. The purine nucleotides, predominantly ATP and GTP, were present at values similar to adults. In the 13 children with $\mathrm{PbB} 30-72 \mu \mathrm{g} / \mathrm{dl}$ $(45.3 \pm 14.3 \mu \mathrm{g} / \mathrm{dl})$, total cytidine phosphates (CMP, CDP, CTP) were significantly $(P<0.001)$ increased from trace values to 8.31 \pm 6.21 nmoles $/ 10^{10}$ erythrocytes. The purine nucleotides were unchanged. P5N activity was $143.3 \pm 22.0$ units/g hemoglobin in children with $\mathrm{PbB}<30 \mu \mathrm{g} / \mathrm{dl}$ and $75.4 \pm 24.2$ units $(P<0.001)$ in the high lead subjects. There was a logarithmic correlation of erythrocyte cytidine phosphates with $\mathrm{PbB}(r=0.89, P<0.001)$ and an inverse correlation of cytidine phosphates with $\ln$ P5N activity $(r=0.59, P<0.001)$, of $\ln \mathrm{P} 5 \mathrm{~N}$ with $\mathrm{PbB}(r=0.64, P<$ $0.001)$ and of $l$ n $P 5 N$ with $l n$ erythrocyte zinc protoporphyrin (Protoporphyrin IX) $(r=0.57, P<0.001)$.
\end{abstract}

\section{Speculation}

The accumulation of small amounts of erythrocyte CTP in children with increased lead exposure but with blood concentrations of leads as low as $30 \mu \mathrm{g} / \mathrm{dl}$ supports a lower threshold for the consequences of lead induced inhibition of pyrimidine $5^{\prime}$-nucleotidase (P5N) than indicated by earlier, less sensitive assays of nucleotides in adults with lead poisoning. The presence of CTP as the predominant pyrimidine nucleotide is similar to the profile in congenital deficiency of P5N but the nucleotides accumulate with less suppression of P5N than found in congenital deficiency. The significance of increased red cell cytidine phosphates at low levels of lead exposure is unknown but it appears to relate to suppression of P5N activity early in red cell maturation, and thus provides an index of antecedant lead exposure that correlates with erythrocyte zinc protoporphyrin.

It is generally accepted that the human erythrocyte is virtually free of pyrimidine nucleotides and is characterized by a selective, possibly unique, enzyme system that favors conservation of the purine nucleotides which serve as the precursors of ATP (25). It was Valentine et al.'s (23) description of a congenital hemolytic anemia characterized by the intraerythrocyte accumulation of pyrimidine nucleotides that led to the definition of a pyrimidine $5^{\prime}$-nucleotidase (P5N) (E.C. 3.1.3.5) in the erythrocyte cytosol. P5N specifically dephosphorylates the pyrimidine nucleoside monophosphates OMP, UMP, and CMP, allowing diffusion from the cell as the soluble nucleosides: cytidine and uridine (14).

Congenital deficiency of P5N, typically with less than $10 \%$ of normal enzyme activity, is relatively frequent among the definable causes of nonspherocytic, familial hemolytic anemia $(11,12,23)$.
It may be manifested by early and recurrent jaundice, has a possibly increased association with mental retardation (6) and is characterized by a basophilic stippling of the erythrocytes resembling lead poisoning. Of analogous interest, P5N is readily inhibited by lead both in vitro and in vivo (14). Clinical studies by ourselves $(2,3,9,11)$ and others $(8,11,16)$ have established the logarithmic suppression of erythrocyte P5N evident at even low levels of blood lead, but the effect of this partial inhibition of P5N on the erythrocyte nucleotides of children has not previously been reported. This is also the first report, employing high performance liquid chromatography technology, of the normal nucleotide profile of young children.

In this study the erythrocyte nucleotides of 25 children, 1-5 years old, were assayed by anion-exchange high performance liquid chromatography to define the values in control subjects and in those previously identified by the Omaha Lead Paint Poison Prevention Program as having an excessive lead burden. At the time of the testing, 13 children had blood leads in the range of 30 $72 \mu \mathrm{g} / \mathrm{dl}$ but none had anemia or reticulocytosis. Assays in these 25 children and 22 others were utilized to define the intercorrelations of blood lead, cytidine phosphates, P5N, and erythrocyte protoporphyrin IX (zinc protoporphyrin or ZPP).

\section{MATERIALS AND METHODS}

The participants in the study were 47 children 1-5 years old followed in the Omaha Lead Paint Poison Prevention Program because of a previous blood lead (PbB) over $30 \mu \mathrm{g} / \mathrm{dl}$ or erythrocyte zinc protoporphyrin (ZPP) over $60 \mu \mathrm{g} / \mathrm{dl}$ and 22 healthy children of the same age range seen in our outpatient clinic. Not all blood samples were adequate for all assays and the distribution of the number of subjects for each of the various combinations of assays was as follows:

\begin{tabular}{lccc}
\multicolumn{1}{c}{ Assay } & Lead Project & Out-Patient & Total \\
ZPP, P5N & 25 & 22 & 47 \\
PbB, P5N & 20 & 22 & 42 \\
PbB, Nucleotides & 19 & 6 & 25 \\
PbB, P5N, Nucleotides & 7 & 5 & 12
\end{tabular}

Because of the significant correlations of data with the standard indices of lead absorption, $\mathrm{PbB}$ and $\mathrm{ZPP}$, the analyses according to the two classes of subjects are not incorporated in the data presentation. Informed parental consent was received for all studies. The study was annually approved by the peer professional review committee of the University of Nebraska Medical Center.

Before nucleotide assay the red cells were first freed of platelets and white cells by elution with 5 volumes of saline from $15 \mathrm{ml}$ syringes packed with equal parts of microcrystalline cellulose and alpha cellulose at $4^{\circ} \mathrm{C}(5,19)$. All assays were performed on venous blood.

Nucleotides were extracted from the erythrocytes by the method of Chen, et al. (9), which involves erythrocyte hemolysis in distilled water, protein precipitation with $10 \%$ trichloracetic acid, and 
neutralization of the trichloracetic acid with tri-N-octylamine in Freon 113 (Matheson Gas Products, Inc.) after centrifugation. The aqueous extracts were immediately frozen at $-17^{\circ} \mathrm{C}$. Samples were analysed within 5 days after extraction but found to be stable at this temperature for several wk. The extraction efficiency was calculated to be $85-100 \%$ for all nucleotides.

The chromatographic system for nucleotide analysis consisted of two model $110 \mathrm{~A}$ pumps and a model 420 microprocessor from Altex Scientific, Inc., Berkeley, CA; a model 1203 fixed wavelength UV detector operating at $280 \mathrm{~nm}$ from Laboratory Data Control, River Beach, FL; and a variable volume sample injector from Rheodyne, Inc., Berkeley, CA. Chromatographic columns were $25 \times 0.46 \mathrm{~cm}$ Partisil 10 SAX anion exchange columns from Altex Scientific, Inc., Berkeley, CA.

Nucleotide separation was accomplished by gradient elution with a low concentration eluent of $0.007 \mathrm{M} \mathrm{KH}_{2} \mathrm{PO}_{4}$ at $\mathrm{pH} 3.90$ and a high concentration eluent of $0.25 \mathrm{M} \mathrm{KH}_{2} \mathrm{PO}_{4}$ and $0.50 \mathrm{M}$

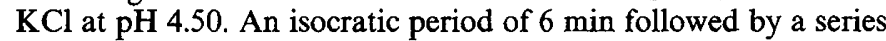
of short linear gradient steps forming a $35 \mathrm{~min}$ concave gradient from $0-100 \%$ enabled complete 5 -nucleotide separation in less than $70 \mathrm{~min}$. The column was then re-equilibrated with $45 \mathrm{ml}$ of the low concentration eluent. The flow rate was constant at 1.5 $\mathrm{ml} / \mathrm{min}$ and the column was at ambient temperature.

Chromatographic peaks were identified by comparison with reference standards from Sigma Chemical Co., St. Louis, MO. Well resolved separations were obtained of the following $5^{\prime}$-nucleotides: the monophosphate ribonucleosides of cytidine (CMP), uridine (UMP), adenosine (AMP), guanosine (GMP), inosine (IMP) and xanthosine (XMP); the di- and triphosphate ribonucleosides of cytidine (CDP and CTP), uridine (UDP and UTP), adenosine (ADP and ATP) guanosine (GDP and GTP), and inosine (IDP and ITP). Quantitation of the nucleotides was accomplished by relative peak areas of the known standards to the internal standard XMP.

P5N activity of erythrocytes was assayed by the method of Torrance, et al. (21). One unit is defined as the enzyme activity that will hydrolyze $1 \mathrm{nmole}{ }^{14} \mathrm{CMP} / \mathrm{min} / \mathrm{g}$ hemoglobin. Whole blood lead was measured by atomic absorption spectroscopy by the microcup method (10). Although red cell lead is a better index of the lead burden than whole blood lead, particularly in anemic subjects, the decision was made to utilize whole blood lead as the more universal standard of exposure. Erythrocyte zinc protoporphyrin was measured by the method of Lamola (13) employing an ESA Zn P Model 4000 hemofluorometer (Cambridge, MA). One ZPP unit is defined as the presence of $1 \mathrm{~g}$ of zinc erythrocyte protoporphyrin/dl whole blood. All values are given as the mean \pm S.D.. Differences in mean values for normal data were analyzed for statistical significance by a one-tailed Student's $t$ test with the Mann-Whitney $U$ test used for non-normal data.

\section{RESULTS}

The chromatographic separation of the erythrocyte nucleotides identified the 13 major 5 -nucleotides.

Blood samples from the six outpatients, considered to be control subjects had either no cytidine phosphates present (four children) or less than 0.25 nmoles $/ 10^{10}$ red blood cells (rbc) (two subjects). As shown in Figure 1, the presence of measurable amounts of cytidine phosphates increased with the blood lead and cytidine phosphates were found in all 10 samples from children with blood leads of $37-72 \mu \mathrm{g} / \mathrm{dl}$. Cytidine phosphates were found in 11 of 13 samples from children with a blood lead $\geq 30 \mu \mathrm{g} / \mathrm{dl}$ but in only four of 12 samples with a blood lead $<30 \mu \mathrm{g} / \mathrm{dl}$.

Since a blood lead of $30 \mu \mathrm{g} / \mathrm{dl}$ is the current level considered indicative of excessive lead exposure, the nucleotide profiles were examined for these two groups. (Table 1). The 13 children with a $\mathrm{PbB} \geq 30 \mu \mathrm{g} / \mathrm{dl}(30-72 \mu \mathrm{g} / \mathrm{dl})$ had a mean $\mathrm{PbB}$ of $45.3 \pm 14.3$, significantly higher than the $20.3 \pm 6.0 \mu \mathrm{g} / \mathrm{dl}$ of the 12 children with a PbB of $8-29.9 \mu \mathrm{g} / \mathrm{dl}$. The content of the purine nucleotides, of IMP and UDP and UMP were comparable for the two groups and resembled the nucleotide profile of normal adults. The ATP content of $1322.2 \pm 279.6$ nmoles $10^{10}$ rbc was similar to the 1204.7

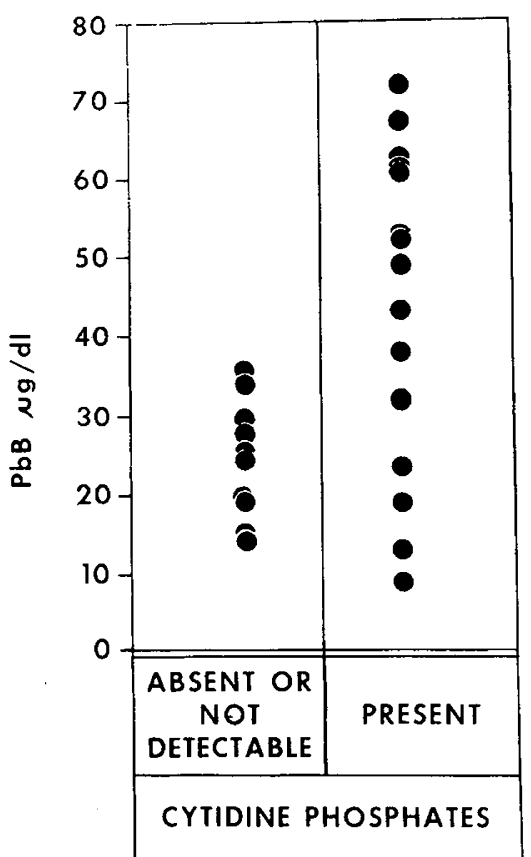

Fig. 1. Of 25 red cell samples, cytidine phosphates were found in 15 . All subjects with blood leads $>38 \mu \mathrm{g} / \mathrm{dl}$ had measurable amounts. No cytidine phosphates were found in the erythrocytes of eight of 12 children $1-5 \mathrm{yr}$ old with a blood lead $(\mathrm{PbB})<30 \mu \mathrm{g} / \mathrm{dl}$; measurable amounts were found ir 11 of 13 samples from children with blood lead $\geq 30 \mu \mathrm{g} / \mathrm{dl}$.

\begin{tabular}{lcc} 
Table 1. Erythrocyte nucleotides nmoles $/ 10^{10}$ & $R B C, \bar{X} \pm$ S.D. \\
& Children $1-5$ yrs old \\
Nucleotide & $\mathrm{PbB} \geq 30 \mu \mathrm{g} / \mathrm{dl}$ & $\mathrm{PbB}<30 \mu \mathrm{g} / \mathrm{dl}$ \\
ATP & $n=13$ & $n=12$ \\
ADP & $1285.17 \pm 320.40$ & $1209.17 \pm 341.27$ \\
AMP & $216.0 \pm 160.02$ & $152.73 \pm 49.45$ \\
GTP & $56.67 \pm 17.68$ & $30.3 \pm 11.13$ \\
GDP & $109.15 \pm 49.72$ & $81.96 \pm 35.65$ \\
GMP & $31.04 \pm 31.72$ & $21.14 \pm 3.59$ \\
IMP & $2.92 \pm 1.45$ & $15.4 \pm 27.60$ \\
CTP & $64.5 \pm 54.34$ & $65.96 \pm 38.49$ \\
CDP & $10.64 \pm 10.65^{1}$ & $0.02 \pm 0.07$ \\
CMP & $3.88 \pm 5.87$ & $0.00 \pm 0.06$ \\
UTP & $0.56 \pm 0.84$ & $0.29 \pm 0.50$ \\
UDP & $1.27 \pm 2.39$ & $0.60 \pm 0.00$ \\
UMP & $2.44 \pm 2.75$ & $0.27 \pm 0.85$ \\
PbB $\mu \mathrm{g} / \mathrm{dl}$ & $5.87 \pm 8.67$ & $6.73 \pm 9.96$ \\
\hline
\end{tabular}

${ }^{1} P<0.001$, Mann-Whitney U test.

\pm 323.1 of the low lead subjects and to the generally accepted adult value of 1000 nmoles $/ 10^{10}$. The only difference in the erythrocyte nucleotide profiles between the two groups was the significant $(P<0.001$, Mann-Whitney $U$ test $)$ increase in the cytidine phosphates, primarily as CTP, in the samples from the 13 children with $\mathrm{PbB} \geq 30 \mu \mathrm{g} / \mathrm{dl}$, in contrast to the trace values of the 12 children with $\mathrm{PbB}<30 \mu \mathrm{g} / \mathrm{dl}$. In the high lead group, CTP was increased to $10.64 \pm 10.65 \mathrm{nmoles} / 10^{10} \mathrm{rbc}$.

Samples from 15 children, 11 of whom had $\mathrm{PbB} \geq 30 \mu \mathrm{g} / \mathrm{dl}$, had measurable amounts of cytidine phosphate. As shown in Figure 2, there was a significant logarithmic correlation of total erythrocyte cytidine phosphate content, in nmoles $/ 10^{10} \mathrm{rbc}(\mathrm{Y})$ with $\mathrm{PbB} \mu \mathrm{g} / \mathrm{dl}(\mathrm{X}): \ln \mathrm{Y}=2.44 \ln \mathrm{X}-7.13 ; r=0.89 ; P<0.001$. This regression predicts the accumulation of 329 nmoles of cytidine phosphates at $\mathrm{PbB} 200 \mu \mathrm{g} / \mathrm{dl}$.

The correlation of red cell P5N (Y) and blood lead (X) as determined in 42 children (Fig. 3) again established a significant inverse logarithmic correlation: $\ln \mathrm{Y}=5.062-0.016 \mathrm{X} ;(r=0.64$; $n=42 ; P<0.001)$. In 27 children with a $\mathrm{PbB}<30 \mu \mathrm{g} / \mathrm{dl}$, P5N activity was $143.1 \pm 22.0$ units/g hemoglobin (mean \pm S.D.), which is similar to our laboratory normal of $148 \pm 20$. In 15 
children with $\mathrm{PbB} \geq 30 \mu \mathrm{g} / \mathrm{dl}, \mathrm{P} 5 \mathrm{~N}$ (mean \pm S.D.) was $75.4 \pm 24.3$ or $53 \%$ of the low lead group.

As shown in Figure 4, P5N was also inversely correlated with ZPP, the index of lead exposure most commonly employed in community programs. Eight of the nine children with ZPP $>60$ $\mu \mathrm{g} / \mathrm{dl}$ had significant decreases in P5N below the normal range of 128-168 units. The regression equation of the correlation of P5N $(\mathrm{Y})$ and $\mathrm{ZPP}(\mathrm{X}), \ln \mathrm{Y}=5.3939-0.23 \ln \mathrm{X}(n=47 ; r=0.57 ; P$ $<0.001$ ) predicts a decrease of P5N to 45 units as ZPP increases to $1000 \mu \mathrm{g} / \mathrm{dl}$.

The correlation of the lead-induced suppression of P5N (X) with accumulation of cytidine phosphates (Y) was investigated in the data from 12 children with measurable amounts of cytidine phosphates: $\mathrm{Y}=59.14-11.48 \ln \mathrm{X} ; r=0.80 ; P<0.001$ (Fig. 5). This regression equation predicts an increase in total erythrocyte cytidine phosphates to only 41 nmoles $/ 10^{10}$ when $\mathrm{P} 5 \mathrm{~N}$ is reduced to 5 units or to less than $5 \%$ of normal.

\section{DISCUSSION}

The red cell nucleotides of children are shown in this study to be quantitatively and qualitatively similar to those of adults. Red

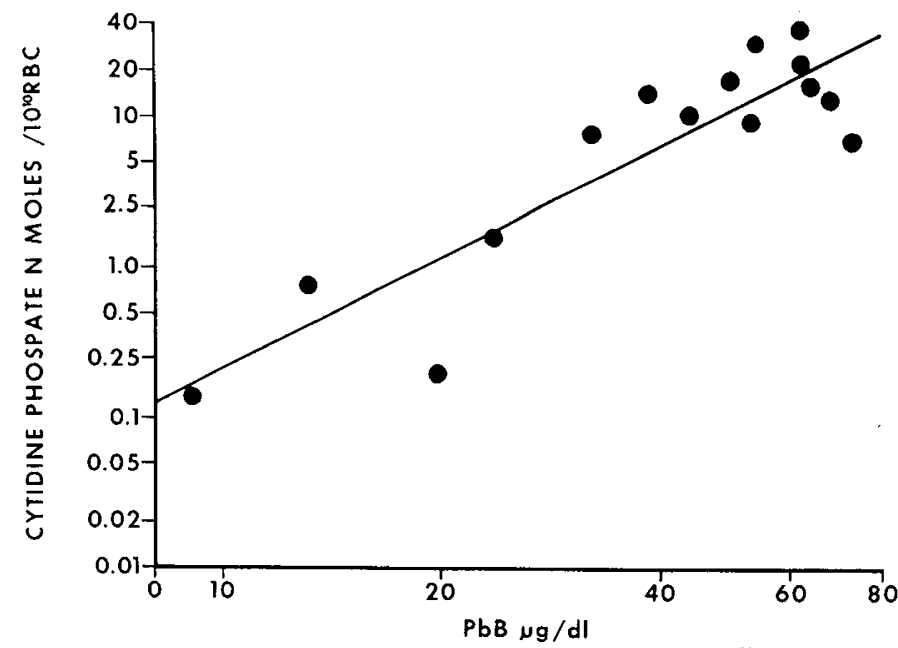

Fig. 2. Total red cell cytidine phosphates in nmoles $/ 10^{10}$ rbc $(\mathrm{Y})$ as related to blood lead ( $\mathrm{PbB} ; \mathrm{X}$ axis) in the 15 children, $1-5$ yr old, with measurable amounts of cytidine nucleotides: $\ln Y=2.44 \ln X-7.13 ; r=$ $0.89 ; P<0.001$. This regression predicts 329 nmoles of cytidine phosphate at a $\mathrm{PbB}$ of $200 \mu \mathrm{g} / \mathrm{dl}$.

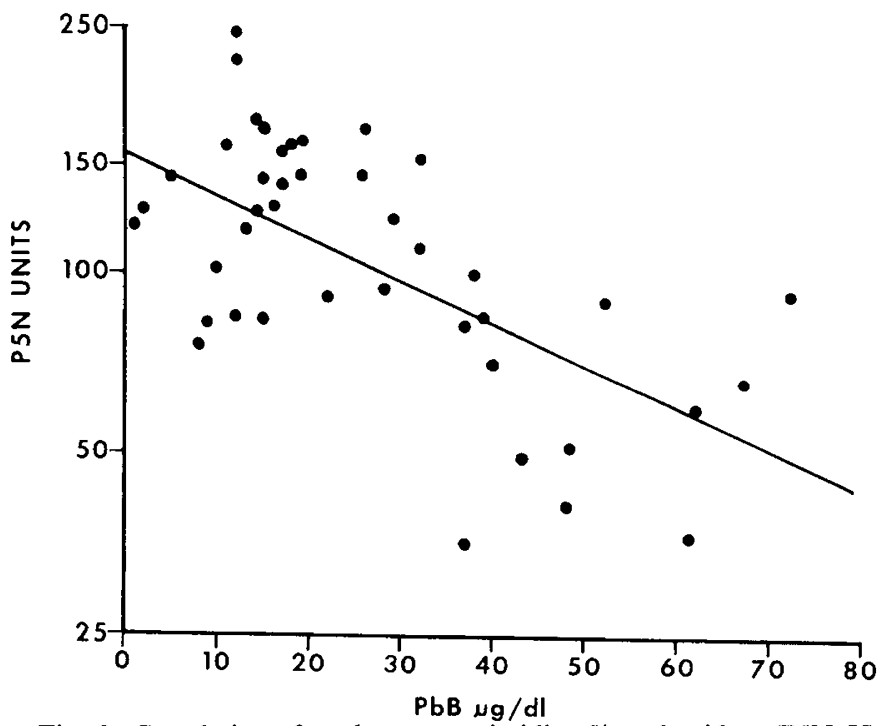

Fig. 3. Correlation of erythrocyte pyrimidine 5 -nucleotidase (P5N; $\mathrm{Y})$ in units defined as the hydrolysis of $1 \mathrm{nmole} \mathrm{CMP} / \mathrm{min} / \mathrm{g}$ hemoglobin with blood lead $\mu \mathrm{g} / \mathrm{dl}(\mathrm{PbB} ; \mathrm{X})$ in 42 children $1-5$ yr old: $\ln Y=5.062-$ $0.016 \mathrm{X} ; r=0.64 ; P<0.001$. This regression predicts $\mathrm{P} 5 \mathrm{~N}$ activity of 1.8 units at a $\mathrm{PbB}$ of $200 \mu \mathrm{g} / \mathrm{dl}$.

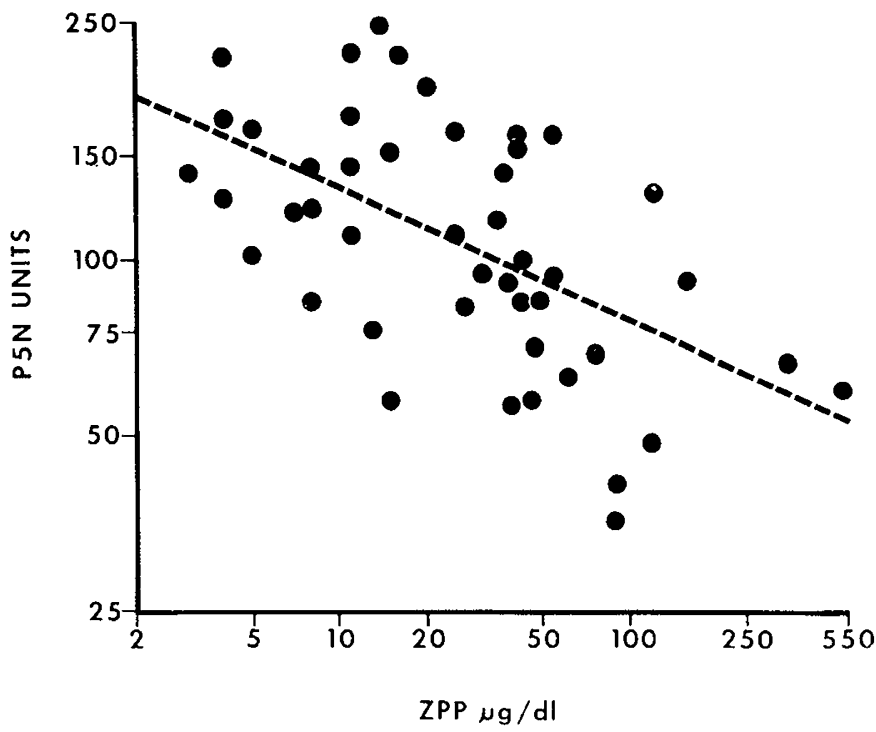

Fig. 4. Correlation of $\mathrm{P} 5 \mathrm{~N}$ activity $(\mathrm{Y})$ with erythrocyte zinc protoporphyrin $\mu \mathrm{g} / \mathrm{dl}(\mathrm{ZPP} ; \mathrm{X})$ as predicted by data from 47 children: $\ln Y=5.3929$ $-0.23 \ln \mathrm{X} ; r=0.57 ; P<0.001$.

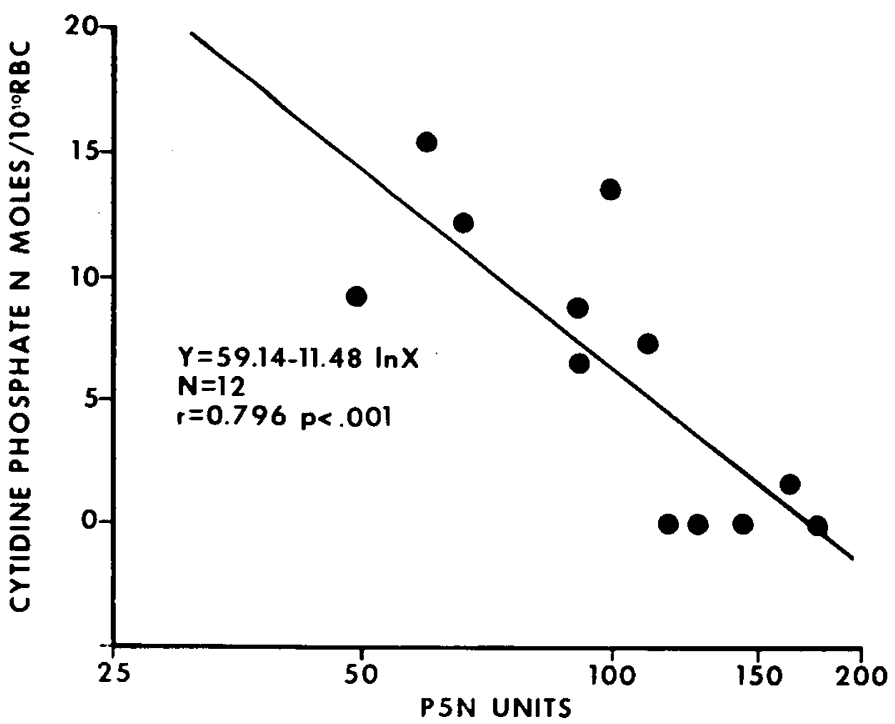

Fig. 5. Correlation of total red cell cytidine phosphates nmoles $/ 10^{10}$ rbc (Y) with erythrocyte $\mathrm{P} 5 \mathrm{~N}(\mathrm{X})$ in 12 children, $1-5$ years old: $\mathrm{Y}=59.14$ $11.48 \ln \mathrm{X}$; this predicts 41 nmoles cytidine phosphate when P5N activity is reduced to 5 units.

cells are normally free of pyrimidine nucleotides except for small amounts of UDP. In this study of children 1-5 years old, detectable increases in pyrimidine nucleotides, primarily as cytidine triphosphate, correlated with increases in the blood lead and concomitant suppression of the pyrimidine-specific 5 -nucleotidase of the red cell cytosol (P5N).

The sensitivity of the high performance liquid chromatography assay of red cell nucleotides made it possible to show the accumulation of cytidine phosphates at blood leads as low as $30 \mu \mathrm{g} / \mathrm{dl}$ and at $\mathrm{P} 5 \mathrm{~N}$ activity of approximately $30-70 \%$ of normal. In congenital deficiency of P5N, spectrophotometric assays have not shown pyrimidine nucleotide accumulation until enzyme activity has been suppressed to below 10\%; in adults with severe, symptomatic lead poisoning, pyrimidines were found when P5N was reduced to $15-16 \%$ activity (16). The slope of the observed correlation of $\mathrm{PbB}$ and $\mathrm{P} 5 \mathrm{~N}$ (Fig. 2) predicts negligible, or $10 \%$, activity of P5N at a blood lead of $147 \mu \mathrm{g} / \mathrm{dl}$ or a red cell lead of $210 \mu \mathrm{g} /$ dl. This is comparable to the prediction by Paglia et al. (16) of complete suppression of enzyme activity at $200 \mu \mathrm{g} / \mathrm{dl}$ of red cell lead. Inasmuch as our previous high performance liquid chro- 
matographic assays of red cell nucleotides in lead-poisoned rabbits showed quantitatively similar responses to this childhood study, apparent differences in the sensitivity of adults and children for accumulation of pyrimidine nucleotides by lead-induced suppression of P5N are thought to relate to the method of assay. The effect of lead-induced suppression, however, may be both quantitatively and qualitatively distinct from the sequelae of congenital deficiency of P5N.

The observed correlation of $\mathrm{PbB}$ and cytidine phosphates (Fig. 1) predicts an increase in cytidine phosphates to only $329 \mathrm{nmoles} /$ $10^{10} \mathrm{rbc}$ at a $\mathrm{PbB}$ of $200 \mu \mathrm{g} / \mathrm{dl}$ despite a concurrent prediction of almost complete suppression of enzyme activity. This is far lower than the massive increases of pyrimidine nucleotides to over 1500 nmoles $/ 10^{10} \mathrm{rbc}$ in persons found homozygous for deficts of P5N activity $(6,12,23,25)$. This would suggest qualitative differences in the sequelae of the two modes of decreased P5N activity as well as differences that may relate to a sustained suppression of P5N throughout erythrocytic maturation in congenital deficiency versus a relatively transient suppression induced by the daily variabilities in blood lead.

The distribution of the erythrocyte pyrimidine nucleotides in children with lead poisoning shows a greater increase in cytidine than uridine phosphates and a predominance of CTP. This is similar to the nucleotide profile noted by Torrance and Whittaker (22) in a child with congenital deficiency of P5N and by our laboratory (19) in studies of lead-treated rabbits. The presence of CTP as the dominant pyrimidine nucleotide is thought to reflect: the relative rate of product formation of P5N for OMP $>$ UMIP " $>$ CMP (15). Continued activity of the diphosphokinases would favor the conversion of CMP $\rightarrow \mathrm{CDP} \rightarrow \mathrm{CTP}$ but any postulated preference for this over the conversion of UMP $\rightarrow$ UDP $\rightarrow$ UTP requires delineation of the enzyme kinetics in the red cell (1).

Although Boninsegna et al. (7) suggest that the soluble fraction of the erythrocyte is unique among blood cells in the activation of UDP $\rightarrow$ UTP by a zinc sensitive enzyme that is distinct from adenylate kinase, there are no comparable studies of erythrocyte activation of CDP $\rightarrow$ CTP. Similarly, additional evidence is required in the mature red cell of the amination of UTP to CTP by CTP synthetase.

In the absence of evidence for a significant de novo synthesis of CTP in the mature erythrocyte, Valentine's view of the pyrimidines as residual to RNA of the normoblast is a more tenable hypothesis concerning the origin of the erythrocyte pyrimidine nucleotides. This is also consistent with our previous studies in lead poisoned rabbits (19), in which lead poisoning induced rapid in vivo suppression of $\mathrm{P} 5 \mathrm{~N}$ with a lag of almost 30 days before cytidine phosphates were detected in the red cell. The accumulation of pyrimidine nucleotides and of stippling peaked at 60 days, the time required in the rabbit for a complete turn over of circulating erythrocytes.

The concept of residual RNA as the source of the pyrimidines is also compatible with the basophilic stippling that is characteristic of both lead-induced suppression and congenital deficiency of P5N. Basophilic stippling is generally accepted as an aggregation of ribosomal RNA around the red cell mitochondria $(4,17$ 18). The precipitation of unstable ribosomes requires the availability of divalent cations or oxidant activity to effect nucleic acid cross-linkage. Beutler (6) implies that lead poisoning and P5N deficiency may have the common denominator of an excess of divalent cation since the red cell stippling of P5N in both states is reversed by EDTA. It can also be proposed that an excess of pyrimidine nucleotides in the young red cell inhibits ribosomal degradation as well as effecting an abnormal charge that would favor aggregation. The simultaneous inhibition of ribosomal degradation by lead may favor ribosomal instability and precipitation at lesser levels of pyrimidine nucleotide accumulation than found in congenital deficiency.

The presence in red cells of a cytosolic nucleotidase (P5N) that specifically dephosphorylates the pyrimidines, facilitating their diffusion with simultaneous conservation of the purines ATP and
GTP, would suggest the possibility that even low levels of pyrimidine nucleotides may exert a toxic effect. It is agreed that leadinduced nucleotidase deficiency can be sufficiently severe to mimic genetic impairment (25). Although the significance of the accumulation of red cell cytidine phosphates at low levels of lead exposure is unknown, it does appear to require suppression of P5N early in red cell maturation and thus provides an index of cumulative lead exposure during the genesis of the circulating red cells. The mechanism is distinct, but the time lapse is similar to the increase in erythrocyte zinc protoporphyrins due to inhibition of heme synthesis.

\section{REFERENCES AND NOTES}

1. Agarwal, R. P., Johnson, B., and Parks, R. E.: Nucleoside diphosphokinase from human erythrocytes. Meth. Enzyme, 51: 376 (1980).

2. Angle, C. R. and McIntire, M. S.: Low level lead and inhibition of erythrocyte pyrimidine nucleotidase. Environ. Res., 17: 296 (1978).

3. Angle, C. R., Stohs, S. J., McIntire, M. S., Swanson, M. S., and Rovang, K. S.: Lead induced accumulation of erythrocytic pyrimidine nucleotides in the rabbit. Toxicol. Appl. Pharmacol., 54: 161 (1980).

4. Bessis, M. and Breton-Gorius, J.: Étude au microscope électronique du sang et des organes hémopoietiques dans le saturnisme experimental. Sémaine hop. Paris, Path. et Biol., 33: 411 (1957).

5. Beutler, E. and West, E.: The removal of leukocytes and platelets from whole blood. J. Lab. Clin. Med., 88: 328 (1976).

6. Beutler, E., Baranko, P. V., Feagler, J., Matsumoto, F., Miro-Quesada, M., Selby, G., and Singh, P.: Hemolytic anemia due to pyrimidine-5'-nucleotidase deficiency: report of eight cases in six families. Blood, 56: 251 (1980).

7. Boninsegna, R., Deana, R., and Siliprandi, D.: The localization of enzymatic activities involved in uridine nucleotides reactions in human erythrocytes. $\mathbf{J}$. Cell. Physiol., 83: 53 (1973).

8.-Buc, H: A. and Kaplan, H. A.: Red-cell pyrimidine 5'-nucleotidase and lead poisoning: Clin. Chim. Acta., 87: 49 (1978).

9. Chen, S..C., Brown, P. R., and Rose, D. M.: Extraction procedures for use prior to HPLC nucleotide analysis using microparticle chemically bonded packings. J. Chromatogr. Sci., 15: 218 (1977)

10. Delves, H. T.: A micro sampling method for rapid determination of lead by blood by atomjc absorption spectrophotometry. Analyst., 95: 431 (1970).

11. Fujii, H.: Role of red cell pyrimidine 5 '-nucleotidase in experimental lead poisoning. Arch. Toxicol., 43; 59 (1979).

12.' Ishida, Y.., Fujii, H., and Miwa, S.: Pyrimidine 5'-nucleotidase deficiency: studies of five cases in two Japanese families. Hemoglobin, 4: 669 (1980).

13. Lamola, A. A:, Joselow, M., and Yamane, T.: Zinc protoporphyrin (ZPP): a simple, sensitive fluorometric screening test for lead poisoning. Clin. Chem., 21.:-93-97 (1975)

14. Paglia, D. E. and Valentine, W. N.: Characteristics of a pyrimidine-specific 5'nucleotidase in human erythrocytes. J. Biol. Chem., 50: 7973 (1975)

15. Paglia, D. E., Valentine, W. H., and Fink, K.: Further observations on erythrocyte pyrimidine nucleotidase deficiency and intracellular accumulation of pyrimidine nucleotidases. J. Clin. Invest., 60: 1362 (1977).

16. Paglia, D. E., Valentine, W. N., and Dahlgren, J. G.: Effects of low-level lead exposure on pyrimidine 5 -nucleotidase and other enzymes. J. Clin. Invest., 56 : 1164 (1975).

17. Sano, S.: Studies on the nature of basophilic stippled cell in lead poisoning. Report I. Studies on the cytological investigation of the basophilic stippled cell. Acta. Haem. Jap., 18: 625 (1955).

18. Sano, S.: Studies on the nature of basophilic stippled cell in lead poisoning. Report 2. Studies on the mechanism of granule formation of basophilic stippled cell in lead poisoning. Acta. Haem. Jap., 18: 631 (1955).

19. Swanson, M. S., Angle, C. R., Stohs, S. J., and Rovang, K. S.: Erythrocyte nucleotides from control and lead treated rabbits. Res. Comm. Chem. Path. Pharmacol, 27: 353 (1980).

20. Tax, W. J. M., Veerkamp, J. H., and Schretlen, E. D. A. M.: Pyrimidine metabolism in erythrocytes of the newborn. Biol. Neonat., 35: 121 (1979).

21. Torrance, J., West, C., and Beutler, E.: A simple rapid radiometric assay for pyrimidine 5'-nucleotidase. J. Lab. Med., 90: 563 (1977).

22. Torrance, J. D. and Whittaker, D.: Distribution of erythrocyte nucleotides in pyrimidine 5'-nucleotidase deficiency. Br. J. Haematol. 43: 423 (1979).

23. Valentine, W. N., Fink, K., Paglia, D. E., Harris, S. R., and Adams, W. S.: Hereditary hemolytic anemia with human erythrocyte pyrimidine 5 '-nucleotidase deficiency. J. Clin. Invest., 54: 866 (1974)

24. Valentine, W. N., Paglia, D. E., Fink, K., and Madokoro, G.: Lead poisoning. Association with hemolytic anemia, basophilic stippling, erythrocyte pyrimidine 5 '-nucleotidase deficiency and intraerythrocytic accumulation of pyrimidines. J. Clin. Invest., 58: 926 (1976).

25. Valentine, W. N. and Paglia, D. E.: Erythrocyte disorders of purine and pyrimidine metabolism. Hemoglobin, 4: 669 (1980).

26. Requests for reprints should be addressed to: Carol R. Angle, M.D., Department of Pediatrics, University of Nebraska Medical Center, 42nd and Dewey Avenue, Omaha, Nebraska 68105 (USA)

27. This research was supported in part by USPHS Grant E.S. 01857.

28. Received for publication September 26, 1980.

39. Accepted for publication August 6, 1981 